\title{
Człowieczeństwo Boga. Sprawozdanie z międzynarodowej konferencji naukowej Towarzystwa Teologów Dogmatyków w dniach 17-19.09.2012 roku
}

Towarzystwo Teologów Dogmatyków zwyczajem lat ubiegłych brało udział w dorocznym spotkaniu, które odbyło się w Białymstoku w dniach 17-19.09.2012 roku. Tegoroczny Zjazd członków Towarzystwa połączono z międzynarodową konferencją naukową na temat Człowieczeństwa Boga. Podjęty problem odzwierciedlił potrzeby współczesnego człowieka, któremu trzeba udzielić odpowiedzi na pytania o Osobę Boga, który stał się człowiekiem. Konferencja została zorganizowana przez ks. prof. dr hab. abp. Edwarda Ozorowskiego we współpracy z ks. dr. Andrzejem Dębskim i ks. dr. Andrzejem Proniewskim. W konferencji wzięło udział blisko osiemdziesięciu teologów duchownych i świeckich, reprezentujących główne ośrodki akademickie z całej Polski i z zagranicy.

W tym roku na miejsce spotkania został wybrany Białystok jako miasto wielu kultur. Lokalizacja konferencji na terenie Podlasia umożliwiła konfrontację z żywą teologią prawosławną. Stało się możliwe także spotkanie muzułmanów tatarskich, co w konsekwencji zaowocowało udziałem w praktycznym doświadczeniu dialogu ekumenicznego i religijnego.

Białostocka konferencja koncentrowała się wokół wyjaśnień człowieczeństwa Boga w kategoriach ludzkich, personalnych i indywidualnych, które znalazły swój wyraz w Osobie Jezusa Chrystusa. W Nim to Bóg stał się człowiekiem i jeszcze przed zaistnieniem świata stał się dla każdego człowieka, żyjącego w konkretnym czasie i określonej historii, niedoścignionym wzorem. Ciągłe poznawanie Osoby Jezusa prowadzi do budowania i przeżywania głębokiej relacji z Nim, co jest niezwykle ważne dla teologów.

Inauguracja konferencji miała miejsce dnia 17.09.2012 roku w pałacu Branickich, gdzie pierwszy wykład pt. Białystok Branickich wygłosił 
ks. dr Jan Nieciecki z Instytutu Historii Sztuki KUL. Następnie ks. dr hab. Krzysztof Guzowski, prof. KUL w swoim referacie wyjaśniał istotę humanizmu Chrystusa, jako Boga bliskiego człowiekowi.

Kolejne sesje odbywały się w Archidiecezjalnym Wyższym Seminarium Duchownym. Środowe spotkanie rozpoczęła msza święta, której przewodniczył abp Edward Ozorowski, Metropolita Białostocki. W homilii przypomniał, że człowieczeństwo Boga jest odwieczne. Uprzedza stworzenie świata i człowieka, a swój punkt kulminacyjny znalazło w Jezusie Chrystusie. „To On jest wzorem człowieczeństwa i wskazuje, co w człowieku, który w Nim osiągnął zbawienie jest najdoskonalsze" - mówił arcybiskup Ozorowski. Zwrócił uwagę, że punktem wyjścia w rozpoznawaniu obecności Boga powinna być wiara prowadząca do metafizyki - credo ut intelligam.

Pierwszy wykład w tym dniu wygłosił abp Jakub, ordynariusz prawosławnej diecezji białostocko-gdańskiej. Wyjaśniał w nim pojęcie i formułę dogmatu chrystologicznego w teologii prawosławnej. Podkreślał, że prawda o „bogoczłowieczeństwie” Chrystusa w ujęciu prawosławia znajduje swój wyraz nie tylko w doktrynie wiary, ale także w liturgii i ikonografii. W swoim referacie abp prof. dr hab. Edward Ozorowski wskazał, na czym polega humanizm unii hipostatycznej w Jezusie Chrystusie. Prelegent podkreślił, że Chrystus, jako doskonały człowiek wyznacza każdemu wierzącemu kierunek wzrastania w człowieczeństwie, którego pełnią jest ostatecznie zmartwychwstanie. Kolejny wykład, ks. prof. dr hab. Hansa Christiana Schmidbauera z Wydziału Teologicznego w Lugano w Szwajcarii, w oparciu o teologię Josepha Ratzingera ukazał naturę oraz podstawowe i metafizyczne atrybuty Boga. Referent stwierdził, że droga człowieka do wiedzy „o tej uniwersalnej rzeczywistości jest czymś więcej niż tylko teorią, ale przede wszystkim żywą prawdą, jest dynamiczna i jest do przebycia, według chrześcijaństwa, w nawiązaniu relacji z Jezusem Chrystusem, jako uniwersalnym konkretem i Logosem wiecznym, który stał się człowiekiem w historii, w którym wieczność niezmienna otwiera się na nas i w którym Bóg naprawdę przyjął kształt i oblicze w świecie - zarówno jako prawdziwy Bóg w osobie, jak też prawdziwy człowiek w osobie". W tym samym dniu uczestnicy konferencji odwiedzili prawosławny monastyr i Muzeum Ikon w Supraślu, silvarium leśnego ogrodu w miejscowości Poczopek w Puszczy Knyszyńskiej, a także zwiedzili meczet tatarski i mizar w Kruszynianach. Wieczorem teolodzy dotarli do kolegiaty pw. św. Antoniego w Sokółce. Tu zatrzymali się na modlitwie adoracyjnej i nieszporach przed Najświętszym 
Sakramentem, który wraz z cząstką Ciała Pańskiego wystawiony jest od roku w kaplicy Matki Bożej Różańcowej.

Dziewiętnastego września uczestnicy konferencji koncelebrowali mszę świętą w sanktuarium Miłosierdzia Bożego w Białymstoku, gdzie spoczywają relikwie bł. ks. Michała Sopoćki. Wizyta w sanktuarium była z jednej strony hołdem wdzięczności bł. ks. Michałowi Sopoćce, profesorowi Seminarium Duchownego w Białymstoku, który życie poświęcił promocji dzieła Miłosierdzia Bożego, z drugiej zaś swoistym gestem przeproszenia za niezrozumienie i krzywdy ze strony teologów, współczesnych ks. Sopoćce, których doświadczył starając się o upublicznienie teologicznych uzasadnień i potrzeby kultu miłosierdzia Bożego. Następnie wysłuchali wykładu ks. prof. dr hab. Jerzego Szymika na temat obrazu Boga w teologii Josepha Ratzingera. Kończący konferencję wykład zatytułowany Człowiek $i$ Trójca. Wewnętrzne życie Boga z perspektywy decyzji stwórczej $w$ teologii Karla Bartha $i$ Karla Rahnera wygłosił ks. dr Robert Woźniak.

Doroczne konferencje Towarzystwa Teologów Dogmatyków mają za zadanie integrację środowiska, które nosi odpowiedzialność za kształtowanie i formowanie właściwej postawy osób wierzących, w szczególny sposób przyszłych duchownych i katechetów. W spotkaniach biorą udział duchowni i świeccy teolodzy z całej Polski oraz goście z zagranicy. Zjazdy te przyczyniają się do integracji środowiska teologicznego i są wyrazem potrzeby budowania wspólnoty ze sobą, dzielenia się przemyśleniami i naukowymi poszukiwaniami, a także wypracowywaniem zbieżnych stanowisk w kwestiach obrony depozytu wiary katolickiej. Niezwykle ważnym elementem dorocznych spotkań jest wspólna Eucharystia oraz modlitwa. 